\title{
AUTOREPORT SISTEM INFORMASI DOKUMEN EVALUASI DIRI PROGRAM STUDI PADA PERGURUAN TINGGI
}

\author{
Yonatan Parassa ${ }^{1)}$ \\ ${ }^{1)}$ Program Sudi Teknik Informatika Politeknik Negeri Manado, 95252 \\ e-mail: yonatan.pa@gmail.com
}

\begin{abstract}
ABSTRAK
Penelitian ini bertujuan membangun sistem informasi dokumen evaluasi diri yang mampu menyajikan data/informasi mengenai dokumen evaluasi diri program studi pada perguruan tinggi secara cepat dan akurat. Metode yang digunakan untuk membangun Sistem informasi dokumentasi evaluasi diri perguruan tinggi adalah metode air terjun. Perangkat lunak yang digunakan untuk membangun sistem ini adalah bahasa pemograman Borland Delphi 7.0. Hasil peneltian menunjukkan bahwa Autoreport sistem Informasi penyusunan dokumen evaluasi diri perguruan tinggi yang dibangun dapat menghasilkan dokumen evaluasi diri program studi yang lebih cepat dari sistem yang digunakan selama. Dengan sistem ini dapat memberikan kemudahan bagi pengelola program studi dalam mengambil keputusan.
\end{abstract}

Kata kunci : autoreport, evaluasi diri, informasi

\section{AUTOREPORT INFORMATION SYSTEM OF SELF-EVALUATION DOCUMENTS OF STUDY PROGRAM IN HIGHER EDUCATION}

\begin{abstract}
The objective of the research was to develop information system of self-evaluation documents of higher education which could present the information concerning self-evalution documents of study program in the higher education quickly and accurately. The method used to develop information System of Self-Evaluation Documents of Higher Education was a water fall method. The sofware used to develop the was the programming language of Borland Delphi 7.0, MySQL Server, ODBC-5.1.6, and Crystal Report 7.0. The result of the research revelas that Autoreport of the information System of Self-Evaluation Documents of Higher Education develop can produce the self-evaluation documents of the the study program faster than the system used, so that it gives easiness for the study program management in making decision.
\end{abstract}

Key-words : Autoreport, information, Self-Evaluation.

\section{PENDAHULUAN}

\section{Latar Belakang}

Evaluasi diri adalah salah satu langkah yang baik dalam peningkatan mutu suatu institusi. Dengan melakukan evaluasi diri dan audit mutu akademik internal akan dapat dipahami bersama oleh segenap anggota satuan pendidikan baik Program studi, Jurusan, Fakultas maupun tingkat Perguruan tinggi segala kelebihan dan kelemahan institusinya sehingga langkah-langkah perbaikan dan titik tekan pengembangan dapat dilakukan dengan tepat sehingga akan menghemat waktu pencapaian tingkat mutu yang dikehendaki.
Kegiatan evaluasi diri dan audit mutu akademik internal dapat dikaitkan atau diikuti oleh evaluasi eksternal atau akreditasi, namun hal ini tidaklah menjadi keharusan, artinya evaluasi diri dan audit mutu akademik internal lebih baik diinternalisasikan sebagai bagian dari budaya peningkatan mutu.

Dokumen evaluasi diri yang proses pembuatannya masih dilakukan secara manual, menimbulkan beberapa masalah yaitu data yang dibutuhkan untuk pembuatan dokumen evaluasi diri belum didokumentasikan dengan baik, demikian pula Dokumen Evaluasi Diri yang dihasilkan. 
Pendekatan pembuatan dokumen evaluasi diri dengan sistem komputer menjadi penting untuk menyelesaikan permasalahan tersebut di atas. Dan untuk pembuatan dokumen evaluasi diri kedepan, yang dihasilkan dilakukan dengan sistem komputerisasi, sehingga data yang dibutuhkan untuk pembuatan Dokumen Evaluasi Diri dapat direkam dan proses penyusunan dokumen evaluasi diri dapat dilakukan dengan waktu yang lebih cepat dan dokumen evaluasi diri yang dihasilkan oleh Sistem dapat didokumentasikan dengan baik untuk memudahkan penyajian Dokumen Evaluasi Diri.

\section{Rumusan Masalah}

Berdasarkan latar belakang permasalahan, maka permasalahan yang dapat dirumuskan adalah sebagai berikut:

1. Bagaimana menganalisis dan mengolah data untuk pembuatan dokumen evaluasi diri

2. Bagaimana membangun perangkat lunak yang dapat menghasilkan dokumen evaluasi diri secara otomatis.

\section{Tujuan Penelitian}

1. Melakukan analisa dan memproses data secara komputerisasi

2. Membangun Sistem Informasi yang dapat menyajikan informasi mengenai Dokumen Evaluasi Diri Program Studi secara cepat dan akurat yang memenuhi standar, baik oleh Badan Akreditasi Nasional Perguruan Tinggi (Ban-PT), Dikrektorat Pendidikan Tinggi (Dikti), dan sesuai dengan kebutuhan Program Studi Teknik Elektro Politeknik Negeri Manado.

\section{TINJAUAN PUSTAKA}

\section{Pengertian sistem}

Sistem adalah kumpulan elemen yang saling berkaitan yang bertanggung jawab memproses masukan (input) sehingga, menghasilkan keluaran (output). (Kusrini, 2007)

Menurut Jogiyanto, 1989 suatu sistem adalah jaringan kerja dari prosedur-prosedur yang saling berhubungan, berkumpul bersama-sama untuk melakukan suatu kegiatan atau menyelesaikan suatu sasaran tertentu.

Sistem adalah sekumpulan hal atau kegiatan atau elemen atau subsistem yang saling bekerja sama atau yang dihubungkan dengan cara-cara tertentu sehingga terbentuk satu kesatuan untuk melaksanakan suatu fungsi guna mencapai tujuan (Sutanta, 2003).

Dari definisi di atas, maka dapat diambil kesimpulan, bahwa sistem adalah totalitas himpunan bagian yang satu sama lain berinteraksi dan bersama-sama untuk mencapai tujuan atau sekelompok tujuan dalam suatu lingkungan. Sedangkan bagian sistem yang biasa disebut juga dengan subsistem, merupakan suatu kumpulan dari unsur tertentu. Dalam mencapai tujuan semua subsistem bekerjasama untuk mencapai tujuan, keharmonisan dan keteraturan yang pasti.

\section{Analisis dan perancangan sistem}

Analisis sistem dapat didefinisikan sebagai penguraian dari suatu sistem informasi yang utuh ke dalam bagian-bagian komponennya dengan maksud untuk mengidentifikasi dan mengevaluasi permasalahan-permasalahan, kesempatan, hambatan dan kebutuhan-kebutuhan sehingga dapat diusulkan perbaikanperbaikannya (Jogiyanto, 1999).

Suatu sistem perlu dianalisis guna menentukan kelemahan-kelemahan sehingga dapat diusulkan perbaikannya. Analisis sistem adalah penguraian dari suatu sistem informasi ke dalam bagian komponenkomponen dengan maksud untuk mengidentifikasikan masalah-masalah, kesempatan, sehingga dapat diusulkan perbaikan-perbaikan.

Untuk mengadakan evaluasi yang luas dan logis terhadap sistem pengolahan data yang sudah berjalan, ada beberapa tahap yang perlu diperhatikan, antara lain:
a. menunjukkan tujuan sistem
b. mempelajari organisasi
c. menganalisis output yang sudah berjalan untuk menentukan kegunaan dalam sistem
d. kebutuhan input
e. evaluasi efektifitas sistem. 


\section{Pengertian sistem basis data}

Sistem basis data merupakan sistem yang terdiri atas kumpulan file (tabel) yang saling berhubungan (dalam sebuah basis data di sebuah sistem komputer) dan sekumpulan program (DBMS) yang memungkinkan beberapa pemakai dan atau program lain untuk mengakses dan memanipulasi file-file (tabel-tabel) tersebut (Fatansyah, 1999).

\section{Autoreport Sistem Informasi}

Penelitian yang dilakukan oleh Abbas Saudek (2010) bertujuan merancang.dan.mengimplementasikan sistem pembagian bunga dana abadi oleh Pemprop Kalimantan Timur kepada Perguruan Tinggi Swasta se Kalimantan Timur. Sistem ini dibangun dari Bahasa Pemograman Delphi 7, menggunakan MySQL sebagai database dan Rave Report untuk laporannya.

Hal yang belum dicapai dari penelitian Abbas Saudek adalah Autoreport yang dihasilkan oleh sistem tidak menyediakan fasilitas untuk mengeksport laporan ke format lain, sehingga laporan yang dihasilkan dari sistem tidak dapat langsung diedit, dan apabila ada kebutuhan yang memerlukan data dari laporan yang merupakan keluaran dari sistem untuk digunakan pada file yang lain, akan membutuhkan kerja ekstra.

\section{Kerangka Konseptual}

Pembuatan dokumen evaluasi diri dibangun melalui beberapa tahapan, dimulai dengan mempelajari pedoman penyusunan dokumen evaluasi diri, membaca dan menganalisa dokumen evaluasi diri yang ada, menentukan dan mengklasifikasikan data yang ada dalam dokumen evaluasi diri, merancang database, merancang interface untuk data masukan, penulisan kode program, dan pengujian sistem.

Sistem ini nantinya akan membuat dokumen evaluasi diri program studi, kecuali analisis SWOT secara komputerisasi sehingga lebih efisien dan efektif dalam pembuatan dokumen evaluasi diri.

Blok diagram untuk kerangka konseptual di atas dapat digambarkan seperti terlihat pada gambar 1 .

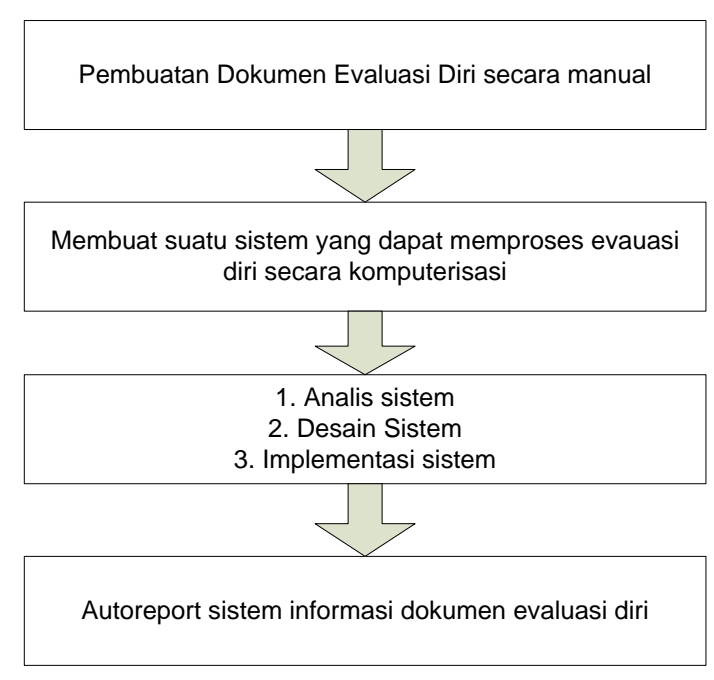

Gambar 1. Kerangka Konseptual

\section{METODE PENELITIAN}

\section{Rancangan Penelitian}

Rancangan penelitian yang diterapkan untuk Autoreport sistem informasi dokumen evaluasi diri program studi Teknik Elektro Politeknik Negeri Manado ini menggunakan model daur hidup pengembangan sistem yang disesuaikan dengan kebutuhan penelitian. Model siklus hidup perangkat lunak yang diterapkan digambarkan sebagai berikut :

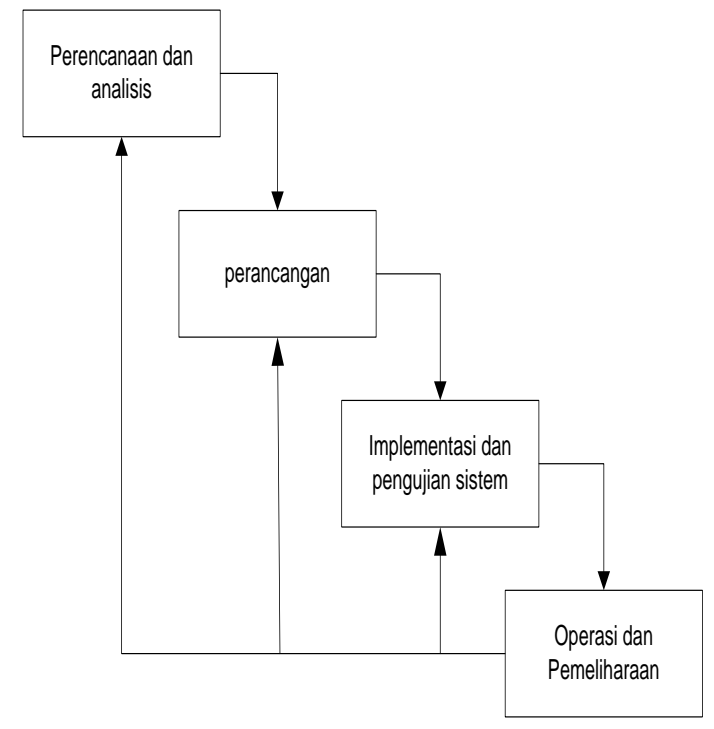

Gambar 2. Model Siklus hidup perangkat lunak autoreport sistem informasi dokumen evaluasi diri program studi Teknik Elektro Politeknik Negeri Manado 
Perencanaan dan analisis adalah menyangkut studi tentang kebutuhan pengguna.

Perancangan sistem, menentukan arsitektur sistem, Model sistem yang mendasar dan hubungan-hubungannya. Pada tahap ini dilakukan perancangan yang meliputi pembuatan konteks diagram, Diagram Berjenjang, Diagram Alir data, hubungan entitas (entity relational), Relasi antar tabel, Perancangan interface dan Perancangan algoritma.

Implementasi dan pengujian unit, realisasi perancangan sebagai serangkaian program atau unit program. Pengujian unit yang sesuai dengan spesifikasi pada tahap perencanaan dan analisis. Koding dan pengujian sistem, menggunakan pengujian blackbox dimana tiap modul diuji apakah sudah sesuai dengan fungsi. Output sistem apakah sudah sesuai dengan yang ditetapkan.

Setelah melalui tahapan diatas, sistem tersebut diimplementasikan yang masuk dalam tahapan operasi dan pemeliharaan. Pemeliharaan mencakup koreksi apabila masih terjadi kesalahan atau mengakomodir kebutuhan-kebutuhan baru.

\section{Lokasi dan Waktu Penelitian}

Penelitian ini dilaksanakan di Program Studi Teknik Elektro Politeknik Negeri Manado, selama 3 bulan dari bulan Juni s.d. September 2010. Tempat ini dipilih mengingat objek yang akan diteliti berada dilokasi ini.

\section{Data yang diperlukan}

Adapun data-data yang diperlukan untuk menyelesaikan masalah dokumen evaluasi diri di Program Studi Teknik Elektro pada Jurusan Teknik Elektro Politeknik Negeri Manado, adalah sebagai berikut:

1. Pedoman Evaluasi diri untuk akreditasi perguruan tinggi yang dikeluarkan oleh BAN-PT edisi 7 (tujuh) Januari 2010.

2. Visi, Misi, Tujuan dan Sasaran, serta Strategi Pencapaian

3. Tatapamong, Kepemimpinan, Sistem Pengelolaan dan Penjaminan Mutu

4. Data Mahasiswa dan Lulusan

5. Data Sumberdaya Manusia
6. Kurikulum, Pembelajaran, dan Suasana Akademik

7. Pembiayaan, Sarana dan Prasarana, dan Sistem Informasi

8. Penelitian, Pelayanan/Pengabdian kepada Masyarakat, dan

9. Kerjasama

10. Dokumen evaluasi diri program studi Teknik Elektro Politeknik Negeri Manado.

\section{Alat yang digunakan}

1. Perangkat lunak pendukung

Perangkat lunak (Software) yang digunakan untuk mengoperasikan program ini adalah:

a. Windows XP .

b. MySQL server untuk Database Manajemen Sistem.

c. Konektivitas menggunakan ODBC versi 5.

d. Borland Delphi Ver. 7.0

e. Crystal Report Versi 7.0

f. Browser internet

g. Microsoft Office 2007

h. Notepad

i. Acrobat Reader

2. Perangkat keras pendukung Spesifikasi perangkat keras (Hardware) yang digunakan untuk menjalankan program ini adalah:

a. Prosesor Pentium IV 2,66 GHz

b. Hardisk $40 \mathrm{~GB}$

c. Memory $512 \mathrm{Mb}$

d.Monitor 14",

e.Printer

\section{Teknik Pengumpulan Data}

Dalam pengumpulan data sebagai bahan masukan menggunakan beberapa cara, diantaranya :

1. Observasi

Metode observasi dilakukan mulai dari bagaimana Tim Pembuatan dokumen evaluasi diri mengumpulkan data, sampai pencetakan dokumen evaluasi diri.

\section{Wawancara}

Wawancara dilakukan baik dengan Tim Kerja, Ketua Program Studi Teknik Elektro, Ketua Jurusan Teknik Elektro, maupun dengan staf administrasi yang terlibat dalam pembuatan dokumen evaluasi diri. 


\section{Analisis Sistem}

Analisis sistem adalah suatu metode pengembangan untuk menganalisis sistem yang ada ke arah pengembangan spesifikasi sistem yang baru.

Tujuan analisis sistem adalah menentukan kebutuhan pemakai secara akurat yang berarti :

a. Jelas dalam dokumentasinya

b. Semua informasi yang diinginkan telah dimasukkan secara lengkap

c. Mudah dimengerti oleh pengguna

d. Konsisten

e. Tepat dan spesifik, dimana semua kebutuhan digambarkan dengan jelas dan pasti.

Sistem yang akan dianalisis adalah sistem tentang proses pembuatan dokumen evaluasi diri sesuai dengan yang tertuang pada pedoman evaluasi diri untuk akreditasi program studi dan institusi perguruan tinggi yang dikeluarkan oleh BAN-PT, yaitu :

1. Keadaaan Awal

a. Proses pembuatan laporan evaluasi diri oleh program studi teknik elektro dilakukan secara manual.

b. Data-data yang dibutuhkan dalam penyusunan dokumen evaluasi diri belum didokumentasikan dengan baik.

2. Kemampuan yang diharapkan setelah adanya sistem ini adalah

a. Proses pengolahan data dapat dilakukan dengan cepat dan akurat.

b. Sistem ini menyajikan informasi mengenai laporan evaluasi diri secara berkualitas, efektif dan efisien yang diharapkan dijadikan bahan pertimbangan untuk pengambilan keputusan.

\section{Pengujian Sistem}

Pengujian aplikasi autoreport sistem informasi dokumen evaluasi diri program studi Teknik Elektro Politeknik Negeri Manado menggunakan teknik acceptance testing pada kategori functionality. Acceptance testing merupakan salah satu model testing yang digunakan untuk mengetahui apakah user meneerima sistem tersebut atau tidak berdasarkan kategori tertentu (Perry, 1995)

Functionality merupakan kategori penerimaan user terhadap sistem ditinjau dari sisi terpenuhi atau tercapai tidaknya kebutuhan user. Faktor-faktor yang mendukung terpenuhinya kategori functionality ditentukan berdasarkan identifikasi kebutuhan user terhadap sistem yang dibuat.

\section{HASIL DAN PEMBAHASAN}

\section{Perancangan Sistem}

Pada tahap ini dilakukan perancangan yang meliputi perancangan arsitektur sistem, Hubungan antar Entitas, Relasi antar tabel, struktur tabel, use case diagram, konteks diagram, diagram berjenjang, diagram alir data

1. Arsitektur Sistem

Sistem manual pembuatan dokumen evaluasi diri pada program studi Teknik Elektro Politeknik Negeri Manado dapat dilihat pada flowchart di bawah ini :

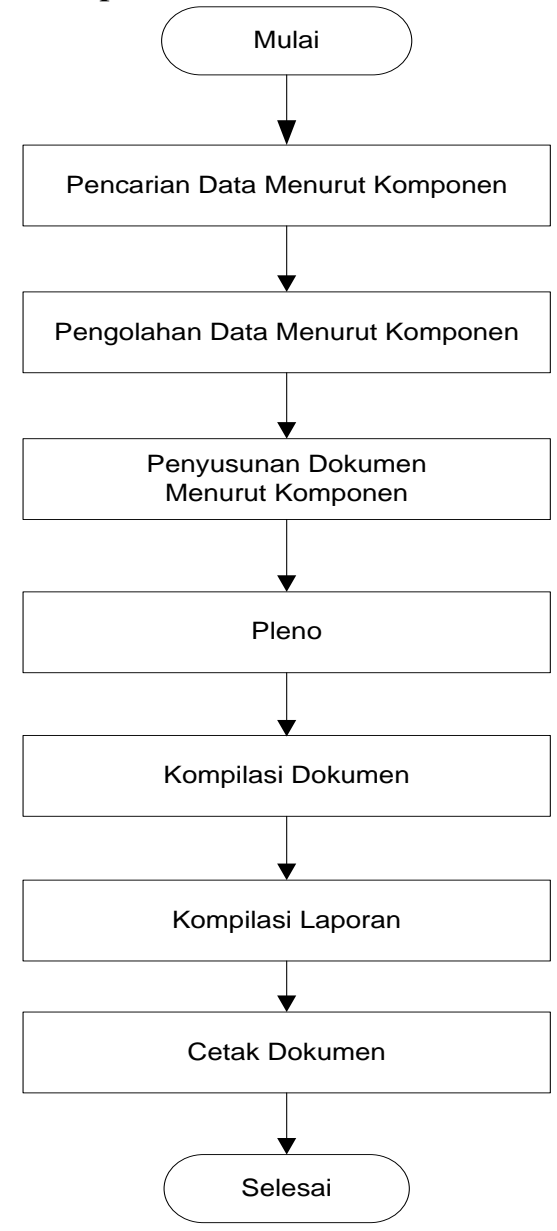

Gambar 3. Flowchart Sistem manual pembuatan dokumen evaluasi diri program studi Teknik Elektro Politeknik Negeri Manado 
Dimulai dengan pencarian data menurut komponen sesuai dengan tugas yang telah ditetapkan, dilanjutkan dengan mengolah data. Setelah itu tahapan penyusunan dokumen menurut komponen. Kemudian dilanjutkan dengan mengkompilasi dokumen dan laporan sebelum mencetak laporan.

Sedangkan flowchart sistem autoreport sistem informasi dokumen evaluasi diri program studi Teknik Elektro Politeknik Negeri Manado dapat dilihat pada gambar berikut :

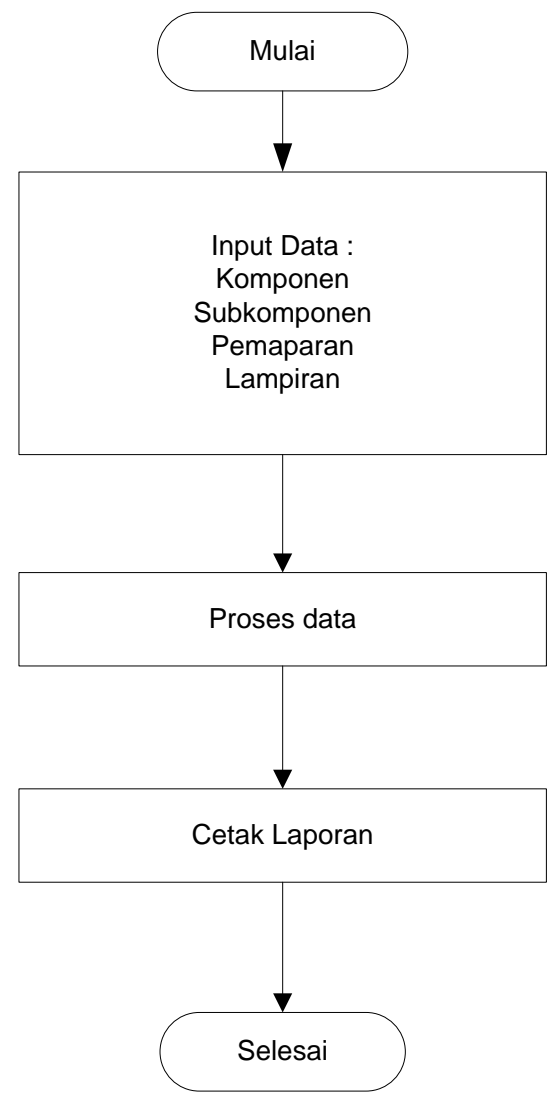

Gambar 4. Flowchart Sistem Autoreport sistem informasi dokumen evaluasi diri program studi Teknik Elektor Politeknik Negeri Manado

Dari gambar 4 dapat dilihat bahwa data-data yang dibutuhkan untuk penyusunan dokumen evaluasi diri diinput untuk kemudian diproses oleh sistem kemudian dicetak untuk menghasilkan dokumen laporan evaluasi diri.

2. Hubungan antar Entitas (entity relationalship Diagram)
3. Relasi Antar Tabel

Relasi antar tabel dapat dilihat pada gambar berikut :

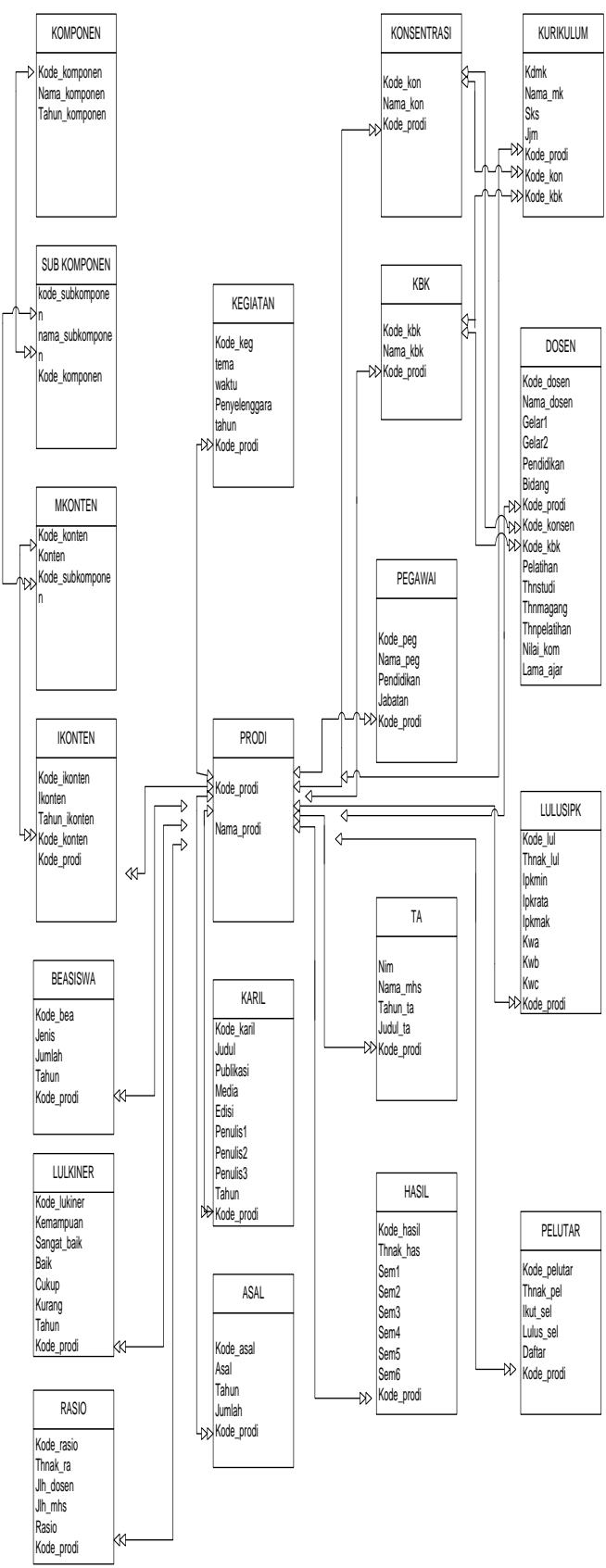

Gambar 5. Relasi Antar Tabel

4. Use Case diagram

Use case diagram dari autoreport sistem informasi dokumen evaluasi diri program studi Teknik Elektro Polikteknik Negeri Manado dapat dilihat pada gambar berikut : 


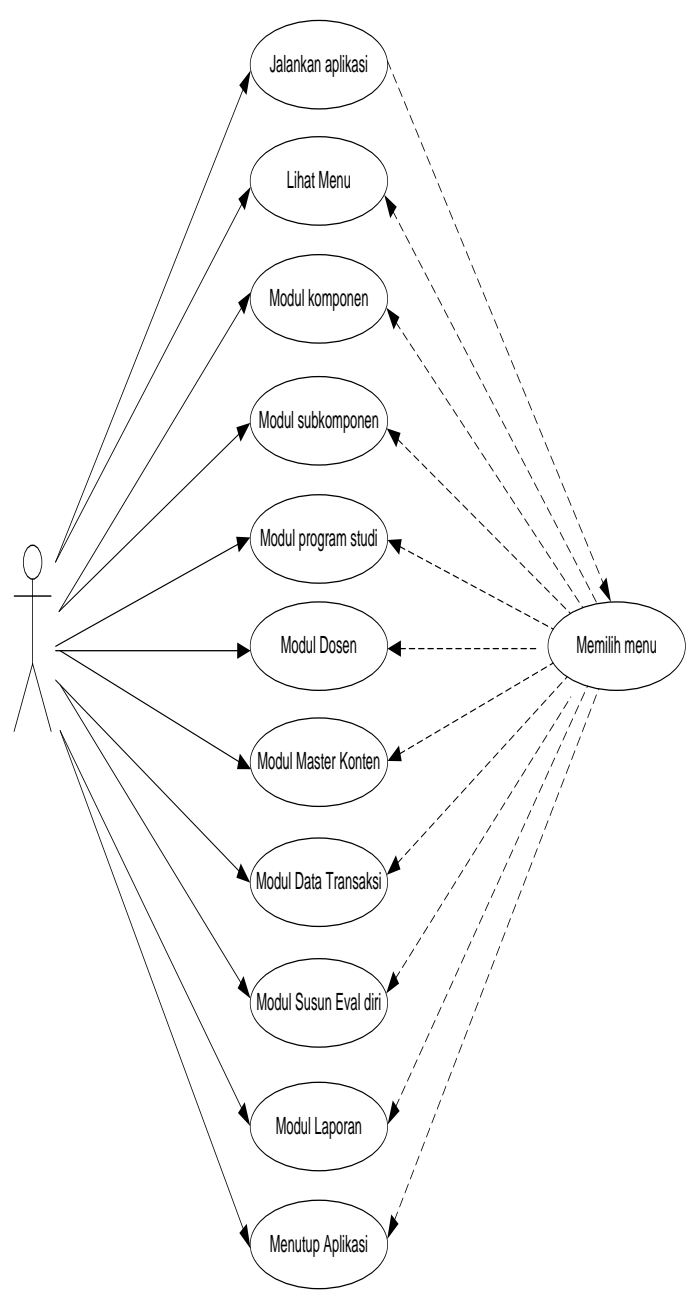

Gambar 6. Use case diagram

\section{Konteks Diagram}

Konteks diagram dari autoreport sistem informasi dokumen evaluasi diri program studi Teknik Elektro Polikteknik Negeri Manado dapat dilihat pada gambar di bawah

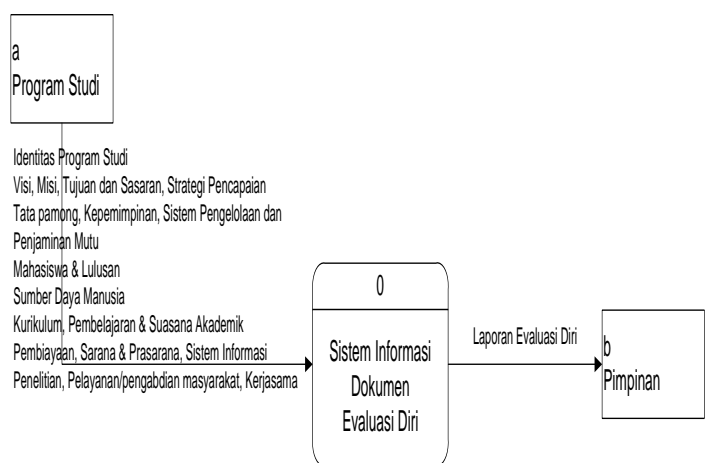

Gambar 7. Konteks Diagram autoreport sistem informasi dokumen evaluasi diri program studi Teknik Elektro Polikteknik Negeri Manado
Diagram konteks menggambarkan alur data ke dalam dan ke luar sistem. Untuk pembuatan diagram konteks, terlebih dahulu menentukan entitas, masukan, dan keluaran.

a. Entitas luar

Entitas luar di sistem ini adalah pimpinan.

b. Masukan

Sistem Informasi Dokumen Evaluasi Diri yang akan dibangun menerima masukan dari program studi berupa data-data yang menyangkut hal-hal: 1) Visi, misi, tujuan dan sasaran, strategi pencapaian; 2) Tata pamong, kepemimpinan, sistem pengelolaan dan penjaminan mutu; 3) Mahasiswa dan lulusan; 4) Sumber daya manusia; 5) Kurikulum, pembelajaran dan suasana akademik; 6) Pembiayaan, sarana dan prasarana, sistem informasi; 7) Penelitian, pelayanan/pengabdian masyarakat, kerjasama; dan 8) data-data tersebut diproses.

\section{c. Keluaran}

Sistem Informasi Dokumen Evaluasi Diri ini akan menghasilkan keluaran, yaitu Dokumen Evaluasi Diri.

6. Diagram Berjenjang

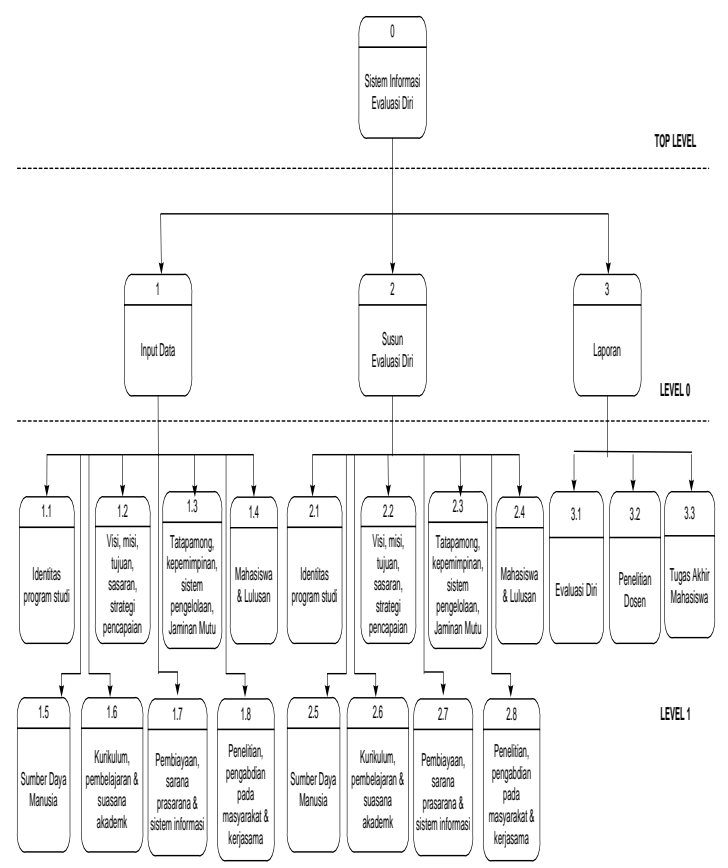

Gambar 8. Diagram Berjenjang Autoreport sistem informasi dokumen evaluasi diri program studi Teknik Elektro Politeknik Negeri Manado 


\section{Implementasi Sistem}

Implementasi dan pengujian unit, realisasi perancangan sebagai serangkaian program atau unit program. Pengujian unit yang sesuai dengan spesifikasi pada tahap perencanaan dan analisis. Koding dan pengujian sistem, menggunakan pengujian blackbox dimana tiap modul diuji apakah sudah sesuai dengan fungsi. Output sistem apakah sudah sesuai dengan yang ditetapkan.

Antarmuka yang nantinya akan digunakan oleh user untuk menjalankan aplikasi didahului dengan mengisi password pada form login, seperti pada gambar berikut

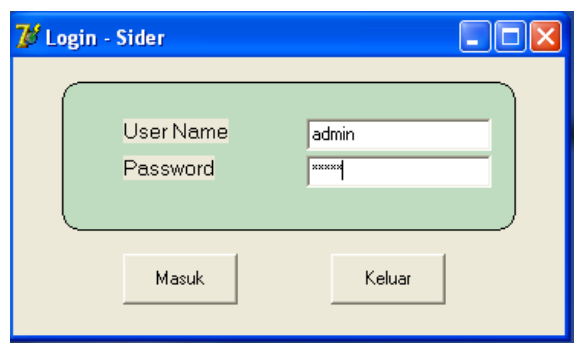

Gambar 9. Form Login

Setelah user mengisi user name dan password dengan benar, maka sistem akan menanggapi dengan memproses menu utama. Tampilan menu utama autoreport sistem informasi dokumen evaluasi diri program studi Teknik Elektro Politeknik Negeri Manado dapat dilihat pada gambar berikut:

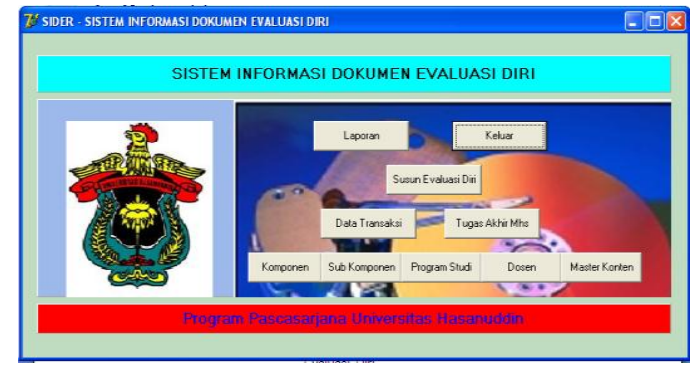

Gambar 10. Form menu awal Sistem Informasi Dokumen Evaluasi Diri

Komponen, Sub komponen, Program Studi, Dosen, Master konten, Penelitian Dosen, Tugas Akhir Mhs, Susun Evaluasi Diri, Form laporan dan untuk keluar dari Sistem Informasi Dokumen Evaluasi Diri.

\section{Pengujian sistem}

a. Pengujian Black box

Sebuah aplikasi yang akan diterapkan haruslah bebas dari kesalahankesalahan atau error. Oleh karena itu, aplikasi harus diuji coba terlebih dahulu untuk menemukan kesalahan-kesalahan yang mungkin terjadi, pengujian ini menggunakan metoda pengujian black box. Pengujian black box berfokus pada persyaratan fungsional perangkat lunak. Pengujian ini berusaha menemukan kesalahan antara lain :

1) Fungsi-fungsi yang tidak benar atau hilang

2) Kesalahan interface

3) Kesalahan dalam struktur data

4) Kesalahan kinerja

Pengujian perangkat lunak Sistem

Informasi Dokumen Evaluasi Diri ini menggunakan data uji berdasarkan form yang terdapat dalam aplikasi dari sistem.

b. Acceptance Testing

Program aplikasi autoreport sistem informasi dokumen evaluasi diri program studi Teknik Elektro Politeknik Negeri Manado juga diujikan dengan teknik acceptance testing. Pengujian acceptance testing dengan kategori functionality. Hasil pengujian adalah sebagai berikut :

Tabel 1. Hasil acceptance testing untuk kategori functionality

\begin{tabular}{|l|l|}
\hline \multicolumn{1}{|c|}{$\begin{array}{c}\text { Identifikasi } \\
\text { Kebutuhan }\end{array}$} & \multicolumn{2}{|c|}{ Terpenuhi } \\
\hline $\begin{array}{l}\text { Input data pemaparan } \\
\text { setiap komponen }\end{array}$ & $\sqrt{ }$ Ya $\quad \square$ Tidak \\
\hline $\begin{array}{l}\text { Input data lampiran } \\
\text { setiap komponen }\end{array}$ & $\sqrt{\mid}$ Ya $\quad \square$ Tidak \\
\hline $\begin{array}{l}\text { Keluaran Dokumen } \\
\text { Pemaparan }\end{array}$ & $\sqrt{ }$ Ya $\square$ Tidak \\
\hline Keluaran lampiran & $\square$ Ya $\square$ Tidak \\
\hline
\end{tabular}

dari tabel hasil pengujian dientas dapat lah form, dim dilihat bahwa program aplikasi autoreport sistem informasi dokumen evaluasi diri program studi Teknik Elektro Politeknik Negeri Manado lulus uji acceptance testing untuk kategori functionality. Hal ini dapat dilihat pada tabel dimana dari 4 identifikasi kebutuhan yaitu input data pemaparan setiap 
komponen, input data lampiran setiap komponen, keluaran dokumen pemaparan dan keluaran berupa lampiran dalam membuat dokumen evaluasi diri semua identifkasi kebutuhan tersebut dapat diakomodir dan proses dengan baik oleh program aplikasi.

\section{KESIMPULAN}

Berdasarkan hasil penelitian sebagaimana telah diuraikan dalam bab sebelumnya, maka dapat disimpulkan sebagai berikut :

1. Aplikasi Autoreport sistem informasi dokumen evaluasi diri adalah suatu aplikasi yang digunakan untuk membantu penyusunan dokumen evaluasi diri.

2. Sistem Informasi Dokumen Evaluasi Diri dengan menggunakan Aplikasi dapat membantu para pimpinan memperoleh informasi secara cepat untuk pengambilan keputusan.

\section{SARAN}

Berikut adalah hal-hal yang disarankan untuk pengembangan Autoreport Sistem Informasi Dokumen Evaluasi Diri Program Studi Teknik Elektro Politeknik Negeri Manado :

1. Aplikasi Autoreport Sistem Informasi dokumen evaluasi diri terbatas pada penyusunan dokumen evaluasi diri, yang selanjutnya dapat dikembangkan sampai kepada analisis SWOT.

2. Kalimat pemaparan masih berdasarkan inputan, dapat dikembangkan kearah kalimat pemaparan yang dicreate berdasarkan data yang ada.

\section{DAFTAR PUSTAKA}

Abbas Saudek. 2010. Autoreport Sistem Informasi Pembagian Bunga Dana Abadi untuk Pembinaan Perguruan Tinggi Swasta se-Kalimantan Timur. Program Pascasarjana Universitas Hasanuddin Makassar.

BAN-PT. 2010. Pedoman Evaluasi Diri untuk Akreditasi Program Studi dan Institusi Pendidikan Tinggi. BANPT, Jakarta.
Dikti. 2009. Siklus Perencanaan. Jakarta : Komisi Program Hibah Kompetisi, (http://www.dikti.go.id), diakses 15 Desember 2009)

Kusrini. 2007. Konsep dan Aplikasi Sistem Pendukung Keputusan. Andi, Yogyakarta.

Perry, W. 1995. Effective Methods for software Testing. John Wiley \& Sons, Inc. Canada.

Sommerville, I. 2003. Software Engineering. Edisi keenam, Erlangga, Jakarta.

Sutanta, Edhi. 2004. Sistem Basis Data Edisi Pertama. Graha Ilmu, Yogyakarta. 